\title{
First report of occurrence of zucchini yellow mosaic virus in Luffa aegyptiaca in India
}

\author{
Savarni Tripathi ${ }^{1} \cdot$ Abhishek Verma $^{1} \cdot$ Sujan Singh Kushwah ${ }^{1} \cdot$ Raj Verma $^{1}$
}

Received: 30 December 2020 / Accepted: 8 April 2021 / Published online: 20 April 2021

(c) Società Italiana di Patologia Vegetale (S.I.Pa.V.) 2021

Keywords ZYMV · CMV · Cucurbitaceae $\cdot$ ELISA $\cdot$ PCR

Luffa aegyptiaca (family Cucurbitaceae) is an important vegetable crop. In July 2019, L. aegyptiaca plants exhibiting mosaic, blistering and deformation of leaves were observed in Pune, India. Average disease incidence was 30 percent in 3 hectares area comprising 12 fields. Leaf samples were collected from 10 symptomatic and 4 asymptomatic plants from different fields and tested by DAS-ELISA using specific polyclonal antibodies (Agdia, IN) against zucchini yellow mosaic virus (ZYMV), cucumber mosaic virus (CMV), cucumber green mottle mosaic virus, and papaya ringspot virus. All 10 symptomatic samples tested positive for ZYMV, of which 6 were also positive for CMV. Asymptomatic plants tested negative for all viruses. Leaf sap of ZYMV positive samples was mechanically inoculated to ten healthy plants of $L$. aegyptiaca cultivar Pusa Chikni, reproducing symptoms similar to field samples. The virus produced chlorotic local lesions on Chenopodium amaranticolor and systemic symptoms on Cucurbita pepo, C. maxima, Cucumis sativus, C. melo, Lagenaria siceraria, Trichosanthes cucumerina and Benincasa hispida, which was confirmed by DAS-ELISA. Total RNA was isolated from symptomatic field, mechanically inoculated and asymptomatic samples of L. aegyptiaca using RNeasy Plant Mini Kit (Qiagen, CA) followed by RT-PCR using ZYMV-specific primers amplifying coat protein C-terminal and 3'UTR (Verma et al. 2006), which yielded ca. 500 bp amplicons from symptomatic and mechanically inoculated samples but not from asymptomatic ones. A consensus sequence of 450 nucleotides was deposited in GenBank (MT070964), showing highest nucleotide identity (99.3\%) with ZYMV

Raj Verma

rajverma0762@gmail.com

1 ICAR-Indian Agricultural Research Institute, Regional Station, Pune-411067, India strain B (AY188994) from Israel. The sequence clustered with other ZYMV sequences in phylogenetic analysis. ZYMV has been reported in cucurbits such as T. cucumerina, Momordica charantia, C. pepo and C. moschata from India (Nagendran et al. 2015), and L. aegyptiaca from Taiwan (Lin et al. 2001). To our knowledge, this is the first report of ZYMV infection in L. aegyptiaca from India.

Supplementary Information The online version contains supplementary material available at https://doi.org/10.1007/s42161-021-00836-y.

\section{Declarations}

Conflict of interest The authors have no conflicts of interest to declare that are relevant to the content of this article.

\section{References}

Lin S-S, Hou RF, Yeh S-D (2001) Complete genome sequence and genetic organization of a Taiwan isolate of Zucchini yellow mosaic virus. Bot Bull Acad Sinica 42:243-250

Nagendran K, Balaji CG, Mohankumar S, Manoranjitham SK, Naidu RA, Karthikeyan G (2015) First report of Zucchini yellow mosaic virus in Snake Gourd (Trichosanthes cucumerina) in India. Plant Dis 99:558. https://doi.org/10.1094/PDIS-10-14-1075-PDN

Verma R, Baranwal VK, Prakash S, Tomer SPS, Singh J, Pant RP, Ahlawat YS (2006) Biological and molecular characterization of Zucchini yellow mosaic virus from naturally infected bottle gourd. Indian J Virol 17:96-101

Publisher's Note Springer Nature remains neutral with regard to jurisdictional claims in published maps and institutional affiliations. 